\title{
Jubileum brněnského slavisty
}

Dne 2. 12. 2018 se dožívá 6o let docent PhDr. Jiř́i Gazda, CSc., zástupce vedoucího Ústavu slavistiky Filozofické fakulty Masarykovy univerzity.

Od absolvování studia všeobecně vzdělávacích předmětů oboru ruština-psychologie na této fakultě v roce 1983 působí J. Gazda na Ústavu slavistiky této fakulty (někdejší Katedře ruského jazyka) nejprve jako asistent, od r. 1988 jako odborný asistent, od r. 2013 jako docent. V letech 1985-1988 absolvoval tamtéž interní vědeckou aspiranturu (jeho školitelem byl prof. PhDr. Jiří Jiráček, DrSc.), jejímž výsledkem bylo dosažení stupně CSc., posléze pak podání a úspěšné přijetí habilitační práce Dynamika jazykových procesư v transformačním a posttransformačním období vývoje ruské společnosti (Brno 2012).

Pedagogická činnost docenta Gazdy zahrnuje jak vlastní složku učitelskou, tj. přednášky, semináře a praktická jazyková cvičení, tak také složku školitelskou, tj. vedení diplomových a doktorských prací a účast v různých druzích zkušebních útvarů. Všechny tyto činnosti realizuje jmenovaný trvale ve vysoké úvazkové normě. Gazdovy přednášky a semináře, obecně zaměřené na lexikologii současné ruštiny v důsledně porovnávacím pojetí s češtinou, se vyznačují řadou charakteristických rysů. Na jedné straně je to aktuálnost daná odrazem společenských přeměn na přelomu 20. a 21. století $\mathrm{v}$ jazyce, ale i snaha o všestrannost podchycení překládaných zeměvědných reálií, o vystižení speciální problematiky obchodní a podnikatelské sféry v jazyce. Jazyku a stylu současné ruské žurnalistiky a publicistiky, který se postupně stává měřítkem spisovného vyjadřování, věnuje zvláštní pozornost. Podobné rysy jsou příznačné pro jeho praktické jazykové kurzy. Na druhé straně je třeba zdůraznit hloubku jeho záběru, jasnost a přehlednost výkladů. Gazdova pedagogická činnost se proto obecně těší příznivému hodnocení posluchačů, jimž imponují i občasné individuální poznámky, kterými přednášející zpestřuje některé suché lingvistické poučky.

Již jako habilitant vedl Gazda 21 diplomových prací bakalářských, 44 magisterských a 13 doktorských, z nichž většina byla již úspěšně obhájena. Účastní se jako člen, nezrrídka jako předseda, zkušebních komisí i pro jiná oborová grémia podobného zaměření. Je autorem vlastních učebních textů a řady jiných pomůcek, které často realizuje ve formě přednášek pro další vzdělávání učitelů apod. Výrazná je v tomto směru Gazdova aktivita při výměnných akcích studentů se zahraničními vysokými školami, jichž se sám účastní jako vedoucí (např. s Nižním Novgorodem).

K teoretickému výzkumu je kromě dvou monografií Jiř́iho Gazdy zaměřeno jeho 65 statí v časopisech a sbornících převážně lexikologického obsahu. I zde je důsledně respektováno konfrontační rusko-české pojetí. Hojná je i Gazdova účast jako redaktora ve 3 slavistických časopisech a editora 5 jazykovědných sborníků. 
Gazdův podíl v pedagogické i výzkumné činnosti se týká nejen jeho vlastního pracoviště: v letech 2002-2006 vykonával funkci proděkana Filozofické fakulty MU a člena kolejní rady MU. Kromě toho působil i v 5 mimouniverzitních jazykovědných asociacích.

Od počátku svého výzkumného působení navazuje Jiří Gazda pracovní kontakty se zahraničními slavisty a rusisty, především z Ruska, Rakouska, Německa, Polska, Madarska a Slovenska. Do této spolupráce se zapojuje jednak jako spoluřešitel mezinárodních projektů zaměřených především na filologicko-areálovou problematiku středoevropského regionu (společné projekty s Institutem slavistiky ve Vídni), jednak individuálně $\mathrm{v}$ rámci vlastních badatelských aktivit, na základě kterých byl pozván na několik zahraničních konferencí a studijních přednáškových pobytů v Rusku, Německu, Rakousku a Madarsku.

V letech 2016-2018 je spoluřešitelem mezifakultního projektu GAMU „Rusko v kategoriích prítel-neprítel - česká reflexe“.

Přejeme jubilantovi do dalších let mnoho tvưrčích sil, zdraví, optimismu a humoru. Stanislav Žaža

\section{https://doi.org/10.5817/OS2018-3-10}

\section{Za Václavem Huňáčkem}

Dne 7. 8. 2018 odešel ve věku 87 let jeden z posledních českých encyklopedistů, doc. PhDr. Václav Huňáček, CSc., jehož univerzální znalosti byly vždy předmětem obdivu a uznání.

Studia ruského jazyka a literatury ukončil na Filozofické fakultě Univerzity Karlovy v polovině 5o. let minulého století spolu se spolužáky, z nichž mnozí se později také stali univerzitními docenty a profesory, zabývajícími se literaturou a jazykovědou. Prožít studia s Milanem Hralou, Bohumilem Neumannem, Vsevolodem Sato, Vladimírem Svatoněm, Jaroslavem Vávrou, Jaroslavem Žákem, Stanislavem Jelínkem, Milanem Balcarem, Miloslavem Dlouhým aj. bylo jistě obohacující i zábavné. Tak na tato léta vzpomínal i prof. Milan Hrala ve své knize Všechno bylo trochu jinak (2014).

Pedagogickou kariéru Václav Huňáček začal na Vysoké škole ruského jazyka a literatury zřízené vládním nařízením $\mathrm{v}$ r. 1952. V souvislosti s následnými reorganizacemi vysokého školství koncem 50 . let přešel na Filozofickou fakultu UK, kde působil více než půl století, at na katedře ruského jazyka a literatury nebo naposledy v Ústavu východoevropských studií. Jeho odborná, vědecká a pedagogická činnost byla velice rozsáhlá a konstatovat, že byl především rusistou a jazykovědcem by bylo nedostačující. 